\title{
ANALISIS PENGARUH RETURN ON EQUITY RATIO (ROE), CURRENT RATIO, DAN DIVIDEND YIELD TERHADAP HARGA SAHAM PERUSAHAAN SEKTOR INDUSTRI BARANG KONSUMSI YANG TERDAFTAR DI BURSA EFEK INDONESIA (BEI)
}

\author{
Fina Nur Aulia Saragih, Ermalina \\ Program Studi Akuntansi ITB Ahmad Dahlan Jakarta, Indonesia \\ Email: finanuraulia@gmail.com, ermalina1962@gmail.com
}

\begin{abstract}
This study aims to examine the analysis of the effect of Return On Equity Ratio (ROE), Current ratio, and Dividend yield on Company Stock Prices in the Consumer Goods Industry Sector Listed on the Indonesia Stock Exchange (IDX). The sample selection in this study using purposive sampling method and obtained 12 companies that match the criteria. The research data was obtained from the Indonesia Stock Exchange. The results of this study are the adjusted R-Square value of 44.1\%. Partially it shows that the Return on Equity Ratio (ROE) and Dividend yield variables have a positive influence on stock prices, while the Current ratio variable also has an influence on stock prices, but not partially. Then, the variables Return on Equity Ratio (ROE), Current ratio, and Dividend yield have a joint or simultaneous effect on stock prices.
\end{abstract}

Keyword : Return on Equity Ratio, Current ratio, Dividend yield, Stock Prices, Consumer Goods Industry

\section{Pendahuluan}

Bagi generasi milenial yang memiliki pemikiran terbuka, menjaga stabilitas ekonomi dan persiapan masa depan merupakan hal yang penting. Hal ini sejalan dengan ungkapan Yuli Rohmiyati (2018, p. 387) yang menyatakan bahwa ciri dari generasi milenial adalah terbuka, orang-orang pada generasi ini siap membuka pikiran dan diri terhadap hal baru yang menjadi trend. Banyak hal yang dapat dilakukan oleh generasi milenial dalam mempersiapkan masa depannya, mulai dari tabungan sampai yang menjadi trend saat ini, yaitu investasi. Ada berbagai macam instrumen investasi yang dapat menjadi pilihan, dimulai dari modal yang kecil hingga cukup besar, ada juga yang dapat dilakukan dengan perhitungan risiko dari yang rendah hingga yang paling tinggi dan ada juga yang dapat langsung memperoleh keuntungan dengan kurun waktu yang lebih cepat atau lebih lambat. Dari berbagai macam investasi tersebut, salah satu investasi yang sangat digemari oleh masyarakat saat ini ialah saham (HSBC, 2019).

Investasi saham ialah investasi yang cukup populer bagi generasi milenial karena memiliki tingkat return yang cukup tinggi. Investor membeli saham dari sebuah perusahaan public karena mengharapkan sebuah return, dimana return dapat berupa dividen atau apresiasi harga saham (Simamora, 2017). Namun, semakin besar return atau imbalan yang investor terima, maka semakin besar pula risiko yang harus diterima. Investor atau pelaku bisnis membutuhkan informasi yang cukup untuk menganalisa lebih lanjut tentang kondisi perusahaan tersebut. Informasi berupa laporan keuangan ini dapat dimanfaatkan oleh investor sebagai pedoman dalam mengambil keputusan investasi karena laporan keuangan tersebut menunjukkan bagaimana prestasi perusahaan di periode yang bersangkutan. 
Saham sendiri diperjual-belikan di Pasar Modal yang merupakan sebuah tempat bertemunya antara perusahaan yang ingin menjual sahamnya dan pembeli yang ingin menginvestasikan uangnya pada saham perusahaan yang dipilihnya. Hal ini sejalan dengan ungkapan Nor Hadi (2015, p. 351) yang menyatakan bahwa pasar modal ialah fasilitas ataupun tempat bertemunya penjual dan pembeli dimana pengibaratan penjual dan pembeli disini yakni penjualan dan pembeli saham dalam rangka investasi.

Di dalam pasar modal terdapat berbagai macam perusahaan, berdasarkan data IDX 2020 ada 708 perusahaan yang sudah go public dan dapat dibeli sahamnya, perusahaan ini dibagi menjadi beberapa sektor industri, salah satunya adalah sektor Industri Barang Konsumsi. Industri ini menjadi salah satu pilihan yang cukup populer bagi investor, karena industri ini yang menyediakan kebutuhan pokok masyarakat sehari-hari. Menurut Menteri Perindustrian, Arilangga Hartarto mengungkapkan "pertumbuhan industri didorong oleh meningkatnya pendapatan masyarakat, tumbuhnya populasi kelas menengah yang disertai kecenderungan pola konsumsi masyarakat yang mengarah untuk mengkonsumsi produk-produk pangan olahan ready to eat" (Kementerian Perindustrian, 2017). Gian Pratama (2019) juga menjabarkan bahwa industri barang konsumsi menjadi kebutuhan pokok masyarakat yang memiliki prospek yang baik dalam jangka panjang karena kebutuhan terhadap industri akan terus bertambah seiring meningkatnya kebutuhan masyarakat, bertambahnya jumlah penduduk, meningkatnya daya beli masyarakat dan pola konsumsi masyarakat yang praktis. Menyadari bahwa industri barang konsumsi ini sangat potensial seharusnya akan memberikan dampak kestabilan terhadap kondisi harga sahamnya di Pasar Saham, namun hal tersebut justru berbanding terbalik dengan kondisi harga saham dari industri ini dalam kurun waktu 5 tahun ke belakang, yaitu pada tahun 2015 sampai dengan 2019.

Pada 2015 harga saham industri ini berada di angka Rp 4.398,- kemudian di tahun 2016 mengalami kenaikan sekitar 114,18\% menjadi Rp 5.121. Pada tahun 2017, rata-rata harga saham sektor barang konsumsi kembali naik dan mencapai angka tertinggi pada 2015, saat itu rata-rata harga saham sektor barang konsumsi ada pada angka Rp 6.240. Harga saham barang konsumsi naik kembali pada tahun 2018 pada angka Rp 6.280 dan turun jauh sebanyak $24.18 \%$ pada tahun 2019 sehingga rata-rata harga saham industri barang konsumsi berada di angka $\mathrm{Rp}$ 4.762. Hal tersebut menjadi fenomena yang menarik untuk dibahas, karena rata-rata harga saham yang cenderung mengalami penurunan tentu akan berdampak kurang baik terhadap perusahaan. Apabila harga saham terus menurun, akan berdampak pada penilaian para pemegang saham terhadap perusahaan, investor akan memberikan penilaian kurang baik terhadap kinerja perusahaan. Investasi juga akan mengalami kemunduran karena kurangnya minat investor untuk memberikan investasi dan akan tercipta stigma bahwa adanya kemunduran kinerja perusahaan dalam mengelola usahanya. Dapat dikatakan demikian, karena harga saham ialah salah satu aspek yang menjadi kriteria kinerja industri ataupun nilai industri.

Ada berbagai aspek yang dapat memengaruhi penurunan harga saham perusahaan, bisasaja terkait internal maupun eksternal. Faktor eksternal ialah faktor yang memengaruhi harga saham dari luar perusahaan salah satunya seperti pertumbuhan ekonomi Indonesia yang melambat. Sedangkan, faktor internal yakni faktor dari dalam perusahaan yang mempengaruhi harga saham, hal tersebut dapat dianalisis secara teknikal maupun fundamental. Menurut Husnan (2015, p. 315), analisis tekhnikal memakai informasi pasar saham meliputi harga serta volume transaksi saham. Sedangkan analisis fundamental memakai informasi keuangan seperti laba, dividen yang akan dibayar, penjualan, dan lainnya. Analisis fundamental dapat dilakukan dengan menganalisis rasio keuangan seperti rasio profitabilitas atau dalam riset ini lebih spesifikasi menggunakan Return on Equity Ratio (ROE) dan rasio likuiditas atau lebih spesifikasi pada Current ratio, selain itu dianalisis melalui kebijakan perusahaan tersebut terhadap dividen yang dibagikan kepada para investor yaitu dengan Dividend yield.

Penelitian ini akan berputar pada permasalahan apakah return on equity ratio, current 
ratiodan dividend yield masing-masing berpengaruh terhadap harga saham dan apakah ketiga variabel tersebut berpengaruh bersama-sama atau simultan terhadap harga saham. Kemudian, perbedaan dengan penelitian sebelumnya, terletak pada objek penelitian dan periode penelitian. Penelitian ini menggunakan objek perusahaan pada industri barang konsumsi yang terdaftar di BEI periode 2015 sampai dengan 2019.

\section{Kajian Teori}

\subsection{Harga Saham}

Saham ialah suatu surat berharga yang menjadi penanda atas bagian hak milik seseorang atau badan usaha dalam suatu perusahaan atau Perseroan Terbatas yang sudah Go Public. Tandelilin (2018) mengungkapkan bahwa saham ialah surat bukti hak milik atas aset-aset ataupun kekayaan perusahaan yang telah menerbitkan saham. Dengan demikian, dapat dikatakan bahwa saham ialah lembaran surat berharga yang dapat dijadikan bukti atas kepemilikan kekayaan perusahaan dan diterbitkan oleh perusahaan Perseroan Terbatas yang sudah Go Public serta dapat diperjual-belikan di Pasar Modal.

Harga saham merupakan harga yang diterapkan untuk selembar saham pada pasar saham. Hal ini sejalan dengan pendapat Musdalifah Aziz (2015, p. 80) bahwa harga saham merupakan harga pada pasar riil yang sangat mudah ditetapkan sebab harga dari selembar saham pada pasar yang sedang berlangsung. Jogiyanto (2015, p. 143) juga sependapat bahwa harga saham yaitu harga yang tertera di pasar bursa pada waktu tertentu dan harga saham tersebut ditetapkan oleh pelaku pasar. Harga saham dapat berubah seiring waktu dibukanya pasar bursa dan bukan suatu rahasia bahwa harga saham selalu mengalami fluktuasi yang cenderung cepat.

\subsection{Return on Equity Ratio (ROE)}

Menurut Kasmir (2015, p. 204), rasio ROE atau rasio pengembalian ekuitas merupakan sebuah rasio yang digunakan untuk mengukur laba bersih setelah dikurangi pajak atau biasa disebut Pendapatan Setelah Pajak (EAT) dengan modal pribadi. Rasio ini bisa menampilkan tingkatan efisiensi perusahaan dalam menggunakan modal sendiri. Semakin besar nilai ROE, oleh karena itu akan semakin baik sebab memperlihatkan kondisi perusahaan yang semakin kokoh, namun jika nilai ROE rendah akan memperlihatkan posisi perusahaan yang lemah. Rasio ini ialah salah satu ratio untuk menaksir nilai profitabilitas perusahaan, dimana kapasitas perusahaan untuk memperoleh keuntungan digambarkan melalui semua sumber daya yang dimiliki oleh perusahaan. Ratio ini dihitung dengan melakukan perbandingan antara laba bersih setelah pajak dengan total modal atau dijabarkan dengan rumus sebagai berikut: $\mathbf{R O E}=($ EAT/Total Modal $) \times 100 \%$.

\subsection{Current ratio}

Menurut Kasmir (2015, p. 134), current ratio atau rasio lancar merupakan rasio yang dipakai untuk menilai likuiditas perusahaan atau kemampuan perusahaan melunasi kewajiban jangka pendek dan utang yang segera jatuh tempo pada saat kreditur menagih secara keseluruhan. Singkatnya, rasio ini mengukur seberapa banyak aset lancar yang tersedia untuk memenuhi semua kewajiban jangka pendek yang segera jatuh tempo. Rasio ini dihitung dengan melakukan perbandingan antara aktiva lancar atau semua aset yang dapat secara cepat dijadikan uang tunai dan hutang lancar atau semua hutang yang harus segera dibayar dalam waktu kurang dalam satu tahun. Rasio ini dijabarkan dengan rumus sebagai berikut: $\mathbf{C R}=$ Aktiva Lancar/Hutang Lancar.

\subsection{Dividend yield}

Menurut Abdul Halim (2015, p. 18), dividen ialah pembagian laba atau keuntungan yang diberikan oleh perseroan kepada investor atas profit yang diterima perusahaan. Deviden 
ialah salah satu return yang akan diterima oleh para pemegang saham saat periode tertentu. Pembagian dividen dilakukan satu tahun sekali setelah ditetapkan dalam Rapat Umum Pemegang Saham, penetapan ini tentunya didasari oleh kebijakan dividen. Kebijakan dividen adalah keputusan yangdilakukan dalam penentuan terkait seberapa besar laba yang diterima perusahaan dalam periode tertentu akan didistribusikan kepada para pemegang saham dalam bentuk dividen (Halim, 2015, p. 135).

Dalam pengukurannya, ada beberapa beberapa ratio yang dapat dihitung seperti Price Earning Ratio (PER), Dividend Payout Ratio (DPR), dan Dividend yield. Pada penelitian ini, peneliti akan menggunakan mengukur dividen dengan Dividend yield. Dividend merupakanukuran untuk menentukan persentase keuntungan yang bersumber dari dividen per lembar saham terhadap harga saham. Pengukuran ini dijabarkan dengan rumus sebagai berikut: Dividen Yield = Dividen per Saham/Harga Saham.

Kerangka Berpikir

\begin{tabular}{|c||l|l|}
\hline Return on Equity Ratio $\left(\mathrm{X}_{1}\right)$ & $\mathrm{H}_{1}$ & \multicolumn{1}{|c|}{ Harga Saham $(\mathrm{Y})$} \\
\hline \hline Current ratio $\left(\mathrm{X}_{2}\right)$ & $\mathrm{H}_{2}$ \\
\hline Dividend yield $\left(\mathrm{X}_{3}\right)$ & $\mathrm{H}_{3}$ \\
\hline
\end{tabular}

$\mathbf{H}^{\mathbf{1}}=$ ROE Berpengaruh Terhadap Harga Saham

H2 $=$ Current ratio Berpengaruh Terhadap Harga Saham

H3 = Kebijakan Dividen Berpengaruh Terhadap Harga Saham

H4 = ROE, Current ratio, dan Kebijakan Dividen Secara Berpengaruh Secara Simultan

TerhadapHarga Saham

\section{Metode Penelitian}

Penelitia ini menggunakan pendektan kuantitatif. Populasi yang digunakan dalam penelitian ini adalah perusaahaan sektor indutri barang konsumsi yang terdaftar di Bursa Efek Indonesia (BEI) tahun 2015 - 2019. Sejumlah 62 Perusahaan akan menjadi populasi riset ini, namun tidak semua populasi akan menjadi objek penelitian, namun hanya perusahaan yang hanya lulus pemilihan kriteria yang akan menjadi sampel penelitian.

Sampel yang digunakan dalam riset ini merupakan beberapa perusahaan yang dipilih dari populasi yang ada dengan menggunakan teknik purposive sampling dimana metode yang membatasi pemilihan sampel didasarkan pada kriteria tertentu. Setelah melakukan pemilihan data yang sesuai dengan kriteria yang ditentukan, maka dapat diketahui bahwa yang menjadi sampel penelitian ada sebanyak 12 perusahaan.

Teknik analisis yang digunakan dalam penelitian ini adalah Penelitian ini menggunakan metode analisis statistik dengan model regresi linier berganda yaitu berfungsi untuk menguji pengaruh antara variabel independen terhadap variabel dependen.Persamaan regresi linier berganda pada penelitian ini adalah sebagai berikut :

$$
Y=a+b_{1} X_{1}+b_{2} X_{2}+b_{3} X_{3} e
$$

\section{Hasil dan Pembahasan}

\subsection{Hasil Penelitian}

\section{Uji Asumsi Klasik}

Menurut Ansofino et al. (2016, p. 93) uji asumsi klasik ialah "persyaratan statistik yang harus dipenuhi pada analisis regresi linear berganda yang berbasis ordinary last square (OLS).”uji asumsi klasik dibagi menjadi 4 yaitu: 


\section{a. Uji Normalitas}

Uji normalitas ialah uji yang dipakai untuk melihat apakah data berdistribusi wajar atau tidak. Untuk melakukan uji normalitas data, peneliti menggunakan uji KolomogorofSmirnov (k-s), dimana dasar pengambilan kesimpulan dengan memandang nilai signifikansi. Apabila nilai signifikansi > 0.05, maka redisual memiliki distribusi yang normal, begitupun sebaliknya (Ghozali, 2016).

Tabel 4.1 Hasil Uji Normalitas

(One Sample Kolmogorov Smirnov)

\begin{tabular}{c|c}
\hline Asymp. Sig. (2-tailed) & Keterangan \\
\hline $\mathrm{N}$ & 60 \\
\hline 0.000 & Data tidak berdistribusi normal \\
\hline
\end{tabular}

Sumber: Hasil analisis data SPSS setelah outlier (lampiran)

Berdasar pada hasil uji normalitas dengan metode one sampel kolmogorov smirnov pada tabel diatas menampilkan bahwa Asymp. Sig. (2-tailed) sebesar 0.000 yang artinya lebih rendah dari syarat 0.05 dan menunjukkan jika data sampel penelitian yang digunakan tidak berdistribusi normal. Oleh karena itu dilakukannya outlier sebagai berikut:

Table 4.2 Hasil Uji Normalitas

(One Sample Kolmogorov Smirnov)

\begin{tabular}{c|c}
\hline Asymp. Sig. (2-tailed) & Keterangan \\
\hline $\mathrm{N}$ & 40 \\
\hline 0.200 & Data berdistribusi normal \\
\hline
\end{tabular}

Sumber: Hasil analisis data SPSS setelah outlier (lampiran)

Berdasar pada hasil uji normalitas dengan metode one sampel kolmogorov smirnov pada tabel diatas menampilkan bahwa Asymp. Sig. (2-tailed) sebesar 0.200 yang artinya lebih tinggi dari syarat 0.05 dan menunjukkan jika data sampel penelitian yang digunakan sudah berdistribusi normal.

\section{b. Uji Multikolenearitas}

Uji multikolinearitas ini digunakan agar mengetahui apakah pada model regresi yang digunakan ditemui korelasi antara variabel independent. Uji multikolinearitas dapatdilakukan dengan memandang nilai Tolerance dan Variance Inflation Factor (VIF) darimasing-masing variabel dengan dasar pengambilan keputusan :

Jika nilai VIF $>10$ dan Tolerance $<0.1$ maka dapat diartika terjadi gejalamultikolinearitas, Jika nilai VIF $<10$ dan Tolerance $>0.1$ maka tidak terjadi masalah multikolinearitas.

Tabel 4.3 Hasil Uji Multikolinearitas

Coefficients ${ }^{\mathrm{a} C o l l i n e a r i t y ~ S t a t i s t i c s}$

\begin{tabular}{lr|r|l}
\hline Model & Tolerance & VIF & $\begin{array}{c}\text { Keteranga } \\
\text { n }\end{array}$ \\
\hline Return on Equity & .639 & 1.565 & Tidak terdapat multikolinearitas \\
\hline Current ratio & .560 & 1.784 & Tidak terdapat multikolinearitas \\
\hline Dividend yield & .627 & 1.596 & Tidak terdapat multikolinearitas \\
\hline
\end{tabular}

Sumber: Data sekunder yang diolah, 2020

Berdasarkan hasil uji multikolinearitas pada tabel di atas menampilkan bahwa nilai tolerance pada variabel-variabel dalam penelitian, yaitu return on equity, current ratio, dividend yield terhadap harga saham menampilkan hasil yang lebih dari 0.10, yakni sebesar 0.639 untuk variabel return on equity, 0.560 untuk variabel current ratio dan 0.627 untuk dividend yield. Selain nilai tolerance, pada tabel juga ditunjukkan nilai VIF dimana masing- 
masing variabel menunjukkan hasil VIF yang tidak lebih besar dari 10, yaitu sebesar 1.565 untuk variabel return on equity, 1.784 untuk variabel current ratio dan 1.596 untuk variabel dividend yield. Berdasarkan hasil tersebut, maka dapat diputuskan bahwa dalam data tidak terdapat multikolinearitas sebab semua variabel memiliki nilai tolerance $>0.10$ dan nilai VIF $<10$.

\section{c. Uji Autokolerasi}

Dalam uji autokolerasi, data akan diolah dengan tujuan untuk melihat apakah dalam suatu model regresi linear adanya keterkaitan yang besar baik positif atau negatif pada data dalam variabel penelitian. Untuk mengetahui ada tidaknya autokolerasi dalam penelitian, maka dilakukanlah uji Durbin Watson (DW test) dengan kriteria pengambilan keputusan sebagai berikut:
a. Terdapat autokolerasi positif, apabila angka DW di bawah -2 .
b. Tidak terdapat autokolerasi, apabila angka DW di antara -2 sampai dengan +2 .
c. Terdapat autokolerasi negatif, apabila angka DW di atas +2 .

Tabel 4.4 Hasil Uji Autokolerasi

\begin{tabular}{ll|l|c|l|l}
\hline Model & $\mathrm{R}$ & $\begin{array}{l}\mathrm{R} \\
\text { Square }\end{array}$ & $\begin{array}{c}\text { Adjusted R } \\
\text { Square }\end{array}$ & $\begin{array}{l}\text { Std. Error of } \\
\text { the Estimate }\end{array}$ & $\begin{array}{l}\text { Durbin- } \\
\text { Watson }\end{array}$ \\
\hline 1 & $.695^{\mathrm{a}}$ & .484 & .4412334 .685 & & .850 \\
\hline
\end{tabular}

Sumber: Hasil analisis data SPSS, 2020

Berdasarkan hasil uji autokolerasi yang dilakukan, diketahui bahwa didapatkan nilai Durbin Watson sebesar 0.850, dimana nilai tersebut berada di antara -2 sampai +2 sehingga dapat dibuktikan bahwa tidak terjadi autokolerasi.

\section{d. Uji Heteroskedastisitas}

Uji heteroskedastisitas ini digunakan untuk mengetahui apakah ada katidaksamaan varian dari residual satu pengamatan ke pengamatan yang lain. Untuk melihat apakah ada gejala heterokedastisitas atau tidak peneliti menggunakan uji Glesjer, dengan pengambilan keputusan :

a. Apabila nilai sig. $>0.05$ maka tidak terjadi heterekedastisitas, sedangkan

b. Apabila nilai sig $<0.05$ maka terjadi gejala heterokedastisitas

Tabel 4.5 Hasil Uji Heteroskedastisitas

\begin{tabular}{|c|c|c|c|c|c|c|}
\hline & & \multicolumn{2}{|c|}{ B Std. Error } & Beta & & \\
\hline \multirow[t]{4}{*}{1} & (Constant) & 641.365 & 884.647 & & .725 & .473 \\
\hline & Return on Equity & 31734.897 & 6771.288 & .702 & 4.687 & .000 \\
\hline & Current ratio & -923.461 & 243.423 & -.607 & -3.794 & .001 \\
\hline & Dividend yield & 637.073 & 291.751 & .330 & 2.184 & .036 \\
\hline
\end{tabular}

Sumber: Hasil analisis data SPSS, 2020

Berdasarkan hasil yang ditampilkan dalam tabel di atas, dapat diketahui bahwa nilai sig. pada variabel-variabel dalam penelitian, di antaranya ROE, current ratio, dan dividend yield terhadap harga saham menampilkan nilai absolute residual yang lebih besar dari 0.05 sehingga dapat dibuktikan bahwa tidak terjadi gejala heteroskedastisitas pada data penelitian.

\subsection{Analaisis Data}

\section{a. Analisis Regresi Linear Berganda}

Analisis regresi linear berganda ialah uji yang dilakukan antar hipotesis pengaruh variabel independen terhadap variabel dependen baik secara parsial maupun bersama-sama (simultan). Model regresi linier berganda ini digunakan untuk variabel penelitian 
independent lebih dari satu meliputi ROE, current ratio dan dividend yield terhadap variabel dependen yaitu harga saham. Pengolahan data regresi linier berganda memakai aplikasi SPSS (Statistical Package for Social Science) 25. Hasil dari analisis ini dapat diketahui pada kolom berikut:

Tabel 4.6 Coeficient

\begin{tabular}{|c|c|c|c|c|c|c|}
\hline & & \multicolumn{2}{|c|}{ B Std. Error } & \multirow[t]{2}{*}{ Beta } & & \\
\hline 1 & (Constant) & 641.365 & 884.647 & & .725 & .473 \\
\hline & Return on Equity & 31734.897 & 6771.288 & .702 & 4.687 & .000 \\
\hline & Current Ratio & -923.461 & 243.423 & -.607 & -3.794 & .001 \\
\hline & Dividend Yield & 637.073 & 291.751 & .330 & 2.184 & .036 \\
\hline
\end{tabular}

Sumber: Data sekunder yang diolah, 2020

Didasarkan pada hasil analisis regresi linear berganda di atas, diperoleh persamaan regresi sebagai berikut: $\mathrm{Y}=\mathbf{6 4 1 . 3 7}+\mathbf{3 1 7 3 4 . 9 R O E}-\mathbf{9 2 3 . 4 6 C R}+\mathbf{6 3 7 . 0 8 D Y}+\mathbf{8 8 4} .65$

Persamaan di atas dapat dijabarkan sebagai berikut:

a) Nilai konstanta $(\alpha)$ sebesar 641.37 menunjukkan bahwa jika variabel ROE, current ratio, dana dividend yield tidak mengalami perubahan maka harga saham memiliki nilai 641.37.

b) Variabel ROE menunjukkan koefisien regresi arah positif dengan nilai sebesar 31734.90, maka menunjukan variabel ROE setiap naik 1 satuan akan menaikkan harga saham sebesar nilai 31734.90 dengan asumsi variabel lain konstan.

c) Variabel current ratio menunjukkan koefisien regresi arah negatif dengan nilai sebesar 923.46, maka ini berarti bahwa variabel current ratio setiap naik 1 satuan akan menurunkan harga saham sebesar -923.46 dengan asumsi variabel lain konstan.

d) Variabel dividend yield menunjukkan koefisien regresi arah positif dengan nilai 637.08, maka ini berarti bahwa variabel dividend yield setiap naik 1 satuan akan menaikkan harga saham sebesar 637.08 dengan asumsi variabel lain konstan.

\section{b. Uji Koefisien Determinasi (R2)}

Uji koefisien determinasi digunakan untuk menilai seberapa jauh pengaruh atau seberapa jauh variabel bebas mampu menjelaskan variabel dependen . Nilai R square adalah antara nol dan satu. Nilai yang mendekati angka satu maka, varibael independen berpengaruh cukup besar terhadap variabel dependen, jika nilai mendekati nol maka menandakan kemampuan variabel independen dalam menjelaskan variasi variabel dependen amat terbatas.

Tabel 4.7 Hasil Uji Koefisien Determinasi $\left(\mathbf{R}^{\mathbf{2}}\right)$

\begin{tabular}{ll|r|r|r}
\hline Model & R & R Square & Adj. R Square & Std. Error of the Estimate \\
\hline 1 & $.695^{\mathrm{a}}$ & .484 & .441 & 2334.685 \\
\hline
\end{tabular}

Sumber: Data sekunder yang diolah, 2020

Didasarkan pada hasil uji di atas, besarnya koefisien determinasi (Adjusted R Square) adalah 0.441 atau $44.1 \%$, hal ini menampilkan bahwa kemampuan variabel independent yaitu ROE, current ratio dan dividend yield menjelaskan sebesar nilai $44.1 \%$ sedangkan sisanya $(100 \%-44.1 \%=55.9 \%)$ dijelaskan oleh variabel bebas lainnya yang tidak diamati dalam penelitian ini.

\section{c. Uji t (Parsial)}

Uji parsial dilakukan dengan tujuan untuk menunjukan seberapa besar pengaruh yang dimiliki suatu variabel independen secara individual dapat menerangkan variabel dependen secara mandiri (Parsial). Uji t dilakukan dengan melakukan komparasi nilai hitung dengan $\mathrm{t}$ tabel dan nilai signifikansi dimana : 
a. Jika nilai signifikasi $<0.05$ maka adanya pengaruh antara variabel independen danvariabel dependen.

b. Jika nilai signifikasi $>0.05$ maka tidak adanya pengaruh antara variabel independen dan variabel dependen

c. Jika $t$ hitung $>t$ tabel memiliki arti adanya pengaruh antara variabel independen dengan variabel dependen secara parsial.

d. Jika $\mathrm{t}$ hitung $<\mathrm{t}$ tabel memiliki arti tidak adanya pengaruh antara variabel independen dengan variabel dependen secara parsial

Tabel 4.8 Hasil Uji t (Parsial)

\begin{tabular}{|c|c|c|c|c|c|c|}
\hline & \multicolumn{3}{|c|}{ Unstandardized Coefficients } & \multirow{2}{*}{$\begin{array}{l}\text { Standardize } \\
\text { d } \\
\text { Coefficients } \\
\text { Beta }\end{array}$} & \multirow[b]{2}{*}{$\mathrm{t}$} & \multirow[b]{2}{*}{ Sig. } \\
\hline & Model & $\mathrm{B}$ & Std. Error & & & \\
\hline 1 & (Constant) & 641.365 & 884.647 & & .725 & .473 \\
\hline & Return on Equity & 31734.897 & 6771.288 & .702 & 4.687 & .000 \\
\hline & Current Ratio & -923.461 & 243.423 & -.607 & -3.794 & .001 \\
\hline & Dividend Yield & 637.073 & 291.751 & .330 & 2.184 & .036 \\
\hline
\end{tabular}

Sumber: Hasil analisis SPSS, 2020

Didasarkan pada hasil yang ditampilkan di atas, maka dapat dilihat bahwa hasil nilai koefisien ROE ( $\beta 1$ ) adalah sebesar 31734.90 dengan nilai signifikan 0.000. Hal tersebut sesuai dengan ketentuan pengambilan keputusan yang telah dijabarkan di atas, dimana signifikansi lebih kecil dari $0.05(0.000<0.05)$, maka H1 diterima. Artinya, adanya pengaruh variabel ROE terhadap harga saham. Apabila dilihat dari t tabel sebesar 2.028 dan t hitung dari ROE adalah 4.687, maka $t$ hitung $>\mathrm{t}$ tabel $(4.687>2.028)$ sehingga dapat disimpulkan bahwa variabel ROE berpengaruh secara parsial terhadap harga saham.

Selanjutnya, pada variabel current ratio menunjukkan hasil nilai koefisien $(\beta 2)$ sebesar -923.46 dengan nilai signifikan 0.001. Dalam hal ini, sesuai dengan ketentuan dimana nilai signifikansi lebih kecil dari $0.05(0.001<0.05)$, maka H2 diterima. Artinya, adanya pengaruh variabel current ratio terhadap harga saham. Apabila dilihat dari t tabel sebesar

2.028 dan t hitung dari Current Ratio adalah -3.794, maka t hitung < t tabel $(-3.794<2.028)$ sehingga dapat disimpulkan bahwa variabel Current Ratio tidak berpengaruh secara parsial terhadap harga saham.

Pada variabel dividend yield menampilkan hasil nilai koefisien ( $\beta 2)$ sebesar 637.07 dengan nilai signifikan sebesar 0.036. Hal tersebut sesuai dengan ketentuan dimana nilai signifikansi lebih kecil dari $0.05(0.036<0.05)$, maka $\mathrm{H} 3$ diterima. Artinya, adanya pengaruh variabel dividend yield terhadap harga saham. Apabila dilihat dari t tabel sebesar 2.028 dan $t$ hitung dari dividend yield adalah 2.184, maka $t$ hitung $>t$ tabel $(2.184>2.028)$ sehingga dapat dibuktikan bahwa variabel dividend yield berpengaruh secara parsial terhadap harga saham.

\section{d. Uji f (Simultan)}

Uji simultan digunakan untuk mengukur pengaruh varibale independen terhaap variabel dependen secara bersama - sama (simultan). Uji F dilakukan dengan membandingkan nilai $\mathrm{F}$ tabel dengan $\mathrm{F}$ hitung dan nilai signifikansi, dimana :

a. Jika nilai signifikasi $<0.05$ maka terdapat pengaruh antara variabel bebas $(\mathrm{X})$ terhadapvariabel terikat (Y).

b. Jika nilai signifikasi $>0.05$ maka tidak terdapat pengaruh antara variabel bebas $(\mathrm{X})$ 
terhadap variabel terikat (Y)

c. Jika F hitung > F tabel berarti ada pengaruh antara variabel independen dengan variabeldependen secara simultan.

d. Jika $\mathrm{F}$ hitung $<\mathrm{F}$ tabel berarti tidak ada pengaruh antara variabel independen dengan variabel dependen.

Tabel 4.9 Hasil Uji f (Simultan) ANOVA ${ }^{a}$

\begin{tabular}{lll|r|r|r|r}
\hline Model & Sum of Squares & df & Mean Square & F & \multicolumn{1}{c}{ Sig. } \\
\hline \multirow{2}{*}{1} & Regression & 183785478.738 & 3 & 61261826.246 & 11.239 & $.000^{\mathrm{b}}$ \\
\cline { 2 - 8 } & Residual & 196227165.037 & 36 & 5450754.584 & & \\
\cline { 2 - 8 } & Total & 380012643.775 & 39 & & & \\
\hline
\end{tabular}

Sumber: Hasil analisis SPSS, 2020

Didasarkan pada hasil yang ditampilkan dalam tabel di atas, maka dapat dilihat bahwa hasil uji Anova atau F hitung adalah sebesar 11.239 dengan probabilitas $0.000<0.05$. Apabila dilihat dari $\mathrm{F}$ tabel sebesar 2.86 , maka $\mathrm{F}$ hitung $>\mathrm{F}$ tabel $(11.24<2.86)$ sehingga dapat disimpulkan bahwa variabel-variabel dalam penelitian, di antaranya ROE, current ratio, dan dividend yield berpengaruh secara bersama-sama atau simultan terhadap harga saham.

\subsection{Pembahasan}

Berdasarkan hasil penelitian dan pengolahan data berupa laporan keuangan perusahaan yang terdaftar di Bursa Efek Indonesia (BEI) dan annual report pada periode 2015 - 2019 yang telah dilakukan, maka akan diuraikan hasil penelitian sesuai dengan permasalahan yang diajukan.Uraian terkait masing-masing variabel dalam pengujian sebagai berikut:

\section{Pengaruh ROE Terhadap Harga Saham}

Hasil penelitian menunjukan bahwa nilai signifikansi dari variabel ROE adalah 0.000 , dimana nilai ini lebih rendah dari 0.05 . Hal tersebut menandakan bahwa berdasarkan hasil pengolahan data, variabel ROE berpengaruh secara signifikan terhadap harga saham. Kemudian, secara parsial, apabila dibanding dari t hitung ROE yang bernilai 4.69 dengan $\mathrm{t}$ tabel yaitu 2.03, maka dapat diketahui bahwa t hitung $>$ t tabel $(4.69>2.03)$. Artinya, ada pengaruh ROE secara parsial terhadap harga saham.

Hasil dari penelitian ini sejalan dengan hasil penelitian yang dilakukan oleh Gian Pratama (2019) dan Ricky Eko Prakoso (2016), yang membuktikan bahwa adanya pengaruh ROE secara signifikan terhadap harga saham. Hal ini disebabkan oleh investor yang melihat kapasitas perusahaan untuk memperoleh keuntungan dari peluang yang ada. Selain itu, Rasio ini bisa menampilkan tingkatan efisiensi perusahaan dalam menggunakan modal sendiri. Semakin besar nilai ROE, oleh karena itu akan semakin baik sebab memperlihatkan kondisi perusahaan yang semakin kokoh, namun jika nilai ROE rendah akan memperlihatkan posisi perusahaan yang lemah. Sehingga hipotesis pertama (H1) yang menyatakan bahwa ROE berpengaruh terhadap harga saham dapat terbukti kebenarannya.

\section{Pengaruh Current Ratio Terhadap Harga Saham}

Hasil penelitian menunjukan bahwa nilai signifikansi dari variabel current ratio adalah 0.001, dimana nilai ini lebih rendah dari 0.05. Hal tersebut menandakan bahwa berdasarkan hasil pengolahan data, variabel current ratio berpengaruh secara signifikan terhadap harga saham. Kemudian, secara parsial, apabila dibanding dari t hitung current ratio yang bernilai 3.80 dengant tabel yaitu 2.03, maka dapat diketahui bahwa t hitung $<\mathrm{t}$ tabel $(-3.80<2.03)$. Artinya, tidak adanya pengaruh current ratio secara parsial terhadap harga saham.

Hasil penelitian ini sejalan dengan hasil penelitian yang dilakukan oleh Gian Pratama (2019), Riris Novitasari (2017), dan Alvin Febianto (2015) yang membuktikan bahwa current ratio tidak berpengaruh terhadap harga saham. Rasio ini ialah salah satu rasio yang dipakai untuk mengukur likuiditas atau singkatnya, rasio ini mengukur seberapa banyak aset lancar 
yang tersedia untuk memenuhi semua kewajiban jangka pendek yang segera jatuh tempo. Rasio ini dihitung dengan melakukan perbandingan antara aktiva lancar atau semua aset yang dapat secara cepat dijadikan uang tunai dan hutang lancar atau semua hutang yang harus segera dibayar dalam waktu kurang dalam satu tahun. Sementara dalam laporan keuangannya, current ratio cenderung stabil sehingga belum menjadi bahan pertimbangan investor untuk memberikan dananya pada perusahaan. Dalam hal ini, diketahui bahwa hipotesis (H2) yang menyatakan current ratio berpengaruh terhadap harga saham ditolak dan tidak terbukti kebenarannya.

\section{Pengaruh Dividend Yield Terhadap Harga Saham}

Hasil penelitian menunjukan bahwa nilai signifikansi dari variabel dividend yield adalah 0.036 , dimana nilai ini lebih rendah dari 0.05 . Hal tersebut menandakan bahwa berdasarkan hasil pengolahan data, variabel dividend yield berpengaruh secara signifikan terhadap harga saham. Kemudian, secara parsial, apabila dibanding dari t hitung dividend yield yang bernilai 2.18 dengan $t$ tabel yaitu 2.03, maka dapat diketahui bahwa $t$ hitung $>\mathrm{t}$ tabel $(2.18<2.03)$. Artinya, ada pengaruh dividend yield secara parsial terhadap harga saham.

Hasil penelitian ini sejalan dengan hasil penelitian yang dilakukan oleh Ricky Eko Prakoso (2016) yang membuktikan adanya pengaruh yang signifikan antara Dividend yield terhadap harga saham. Hal ini disebabkan bahwa dividend yield akan menunjukkan tingkat pengembalian dividend yang akan diterima oleh investor. Sehingga hipotesis ketigas (H3) yang menyatakan bahwa dividend yield berpengaruh terhadap harga saham diterima dan dapat dibuktikankebenarannya.

\section{Pengaruh ROE, Current Ratio, Dividend Yield Secara Simultan Terhadap Harga Saham}

Hasil penelitian menunjukan bahwa nilai signifikansi dari pada uji $\mathrm{f}$ adalah 0.000 , dimana nilai ini lebih rendah dari 0.05 . Hal tersebut menandakan bahwa berdasarkan hasil pengolahan data, maka variabel ROE, Current Ratio, dan dividend yield berpengaruh secara signifikanterhadap harga saham. Kemudian, secara simultan, apabila dibanding dari f hitung bernilai 11.24 dengan $\mathrm{f}$ tabel yaitu 2.86, maka dapat diketahui bahwa f hitung $>\mathrm{f}$ tabel (11.24 <2.86). Artinya, ROE, current ratio dan dividend yield berpengaruh secara simultan terhadap harga saham. Berdasarkan hasil pengolahan data dengan menggunakan uji $\mathrm{f}$ ini, dapat dibukti kan bahwa hipotesis keempat (H4) yang menyatakan bahwa ROE, current ratio, dividend yiel berpengaruh secara simultan terhadap harga saham dapat dibuktikan kebenarannya.

\section{Kesimpulan dan Saran}

\subsection{Kesimpulan}

Penelitian ini dilakukan guna mengetahu pengaru dari ROE, Current Ratio, Dividend Yield terhadap Harga Saham perusahaan yang berada di industri barang konsumsi yang terdaftar di Bursa Efek Indonesia pada periode 2015 - 2019. Didasarkan pada hasil pengolahan data dan analisis yang telah dilakukan, maka akan didapatkan kesimpulan sebagai berikut:

a. Variabel return on equity secara parsial memiliki pengaruh terhadap harga saham.

b. Variabel current ratio memiliki pengaruh terhadap harga saham namun tidak secara parsial.

c. Variabel dividend yield secara parsial memiliki pengaruh terhadap harga saham

d. Variabel return on equity, current ratio, dan dividend yield berpengaruh secara simultanterhadap harga saham.

\subsection{Saran}

Didasarkan pada proses yang dilalui dalam melakukan riset ini, maka peneliti memberikansaran untuk peneliti selanjutnya sebagai berikut:

a. Diharapkan menambah periode riset yang tidak terbatas pada periode $2015-2019$. 
b. Diharapkan untuk menggunakan rasio keuangan lainnya sehingga didapatkan gambaran yanglebih jelas terkait kondisi pasar modal.

c. Diharapkan untuk melakukan analisis teknikal agar mendapatkan data real sesuai yang terjadi di lapangan.

\section{Referensi}

Ahmad, K. (2017). Dasar-dasar Manajemen Investasi dan Portofolio (Edisi Revisi). Jakarta: Rineka Cipta.

Ansofino., J. Y. (2016). Buku Ajar Ekonometrika. Yogyakarta: Deepublish.

Azis, M. (2015). Manajemen Investasi: Fundamental, Teknikal, Perilaku Investor danReturn Saham. Yogyakarta: Deepublish.

Beck, C. (2016, 01 20). Why are Millennials forgoing driving? Diambil kembali dari The Christian Science Monitor: https://www.csmonitor.com/USA/USAUpdate/2016/0120/Why-are-Millennials-forgoing-driving

Ghozali, I. (2016). Aplikasi Analisis Multivariate dengan Program SPSS 21. Semarang:Badan Penerbit Universitas Diponegoro.

Gunawan, I. (2019). Pengaruh Kebijakan Deviden, Profitabilitas dan Laba Akuntansi Terhadap Return Saham dengan Nilai Perusahaan Sebagai Variabel Moderasi. Repositori UIN Alauddin, 44.

Hadi, N. (2015). Pasar Modal. Yogyakarta: Graha Ilmu.

Halim, A. (2015). Manajemen Keuangan Bisnis: Konsep dan Aplikasinya, Edisi Pertama. Jakarta: Mitra Wacana Media.

Houston, B. a. (2017). Fundamental of FinancialManagement: Dasar-Dasar Manajemen Keuangan. Jakarta: Salemba Empat.

HSBC. (2019, Juni). Jenis-jenis Investasi yang Populer di Indonesia. Diambil kembali dari HSBC: https://www.hsbc.co.id/1/PA_esf-ca-appcontent/content/indonesia/personal/offers/news-and-

lifestyle/files/articles/html/201906/jenis-jenis-investasi-yang-populer-diindonesia.html

Husnan, S. (2015). Dasar-Dasar Teori Portofolio dan Analisis Sekuritas (Edisi ke-5). Yogyakarta: UPPN STIM YKPN.

Ikatan Akuntan Indonesia. (2015). Pernyataan Standar Akuntansi Keuangan 1. Jakarta: Salemba Empat.

Ikatan Akuntan Indonesia. (2017). Pernyataan Standar Akuntansi Keuangan. Jakarta: Salemba Empat.

Jogiyanto. (2015). Teori Fortofolio dan Analisis Investasi. Yogyakarta: BPFE. Kasmir. (2015). Analisis Laporan Keuangan. Jakarta: Raja Grafindo Persada.

Kementerian Perindustrian. (2017, Februari 7). Industri Makanan dan Minuman Dorong Pemerataan Nasional. Diambil kembali dari Kementerian Perindustrian Republik Indonesia: https://www.kemenperin.go.id/artikel/16979/Industri-Makanan-danMinuman-Dorong-Pemerataan-Nasional

Marcus, B. K. (2018). Investments and Portofolio Management. Jakarta: Salemba Empat. Pratama, G. (2019). Pengaruh Likuiditas dan Profitabilitas Terhadap Harga Saham (Sektor Industri Barang Konsumsi yang Terdaftar di Bursa Efek Indonesia (BEI) Tahun2014-2018). Repository Indonesia University of Education, 5.

Pratama, G. (2019). Pengaruh Likuiditas dan Profitabilitas terhadapHarga Saham (Sektor Industri Barang Konsumsi yang Terdaftar di Bursa Efek Indonesia (BEI) tahun 20142018). repository.upi.edu, 5.

Rohmiyati, Y. (2018). Model Perilaku Pencarian Informasi Generasi Milenial. EjurnalUndip, 387.

Samsul, M. (2015). Pasar Modal dan Manajemen Portofolio. Surabaya: Penerbit Erlangga. 
Santoso, S. (2016). Statistik Parametik. Jakarta: PT. Gramedia.

Sembiring, L. J. (2019, Agustus 14). Ekonomi RI Cukup Berat, Bahkan Berat Sekali!

Diambil kembali dari CNBC INDONESIA: https://www.cnbcindonesia.com/news/20190813184207-4-91813/ekonomi-ri-cukupberat-bahkan-berat-sekali

Simamora, H. (2017). Keputusan Akuntansi Basis Pengambilan Bisnis (Edisi Revisi). Jakarta: Salemba Empat.

Slamet, Y. S. (2017). Statistik Inferensial. Yogyakarta: Andi. Sugiyono. (2017). Metode Penelitian Kuantitatif, Kualitatif, dan R\&D. Bandung: Alfabeta.

Tandelilin, E. (2017). Pasar Modal: Manajemen Portofolio \& Investasi. Yogyakarta:Kasinus. Tandelilin, E. (2018). Analisis Investasi dan Manajemen Portofolio. Yogyakarta: BPFEYogyakarta.

Widoatmojo, S. (2012). Pasar Modal Indonesia Pengantar \& Studi Kasus. Bogor: Ghalia Indonesia.

Zulfikar. (2016). Pengantar Pasar Modal Dengan Pendekatan Statistika Edisi Pertama. Yogyakarta: Gramedia. 